\title{
PENGARUH PELATIHAN DAN PEMBERIAN REWARD TERHADAP KEPUASAN KERJA PEGAWAI BADAN PUSAT STATISTIK KABUPATEN PIDIE
}

\author{
Husaini Abdullah \\ Program Studi Manajemen \\ Fakultas Ekonomi \\ Universitas Jabal Ghafur
}

\begin{abstract}
ABSTRAK
Penelitian ini bertujuan untuk mengetahui "Pengaruh Pelatihan dan Pemberian Reward terhadap Kepuasan Kerja Pegawai Badan Pusat Statistik Kabupaten Pidie". Dimana variabel independen yaitu Pelatihan (X1), Pemberian Reward(X2), dan Kepuasan Kerja (Y) sebagai variabel dependennya.Populasi dalam penelitian ini adalah pegawai yang bekerja pada Badan Pusat Statistik kabupaten Pidie yang mana jumlahnya 34 Pegawai.Penelitian ini merupakan penelitian populasi.Seluruh populasi dalam penelitian ini diambil sebagai Sampel.Data dikumpulkan dengan menggunakan metode survei melalui kuesioner yang diisi oleh responden.Kemudian data yang diperoleh dianalisis dengan menggunakan analisis regresi berganda. Analisis ini meliputi Uji Validitas, Uji Reliabilitas, Analisis Regresi berganda Uji Asumsi Klasik, Uji Hipotesis melalui Uji F dan Uji t, serta analisis Koefisien Determinasi $\left(\mathrm{R}^{2}\right)$. Berdasarkan hasil penelitian, diperoleh persamaan regresi: $\mathrm{Y}=4,120+0,540 \mathrm{X} 1+0,283 \mathrm{X} 2$.

Berdasarkan hasil analisis di atas dapatdisimpulkan bahwa dari kedua variabel yang diteliti, ternyata variabel Pelatihan (X1)mempunyai pengaruh yang paling dominan sebesar 44,8\%terhadap Kepuasan Kerja (Y) Pegawai di Badan Pusat Statistik Kabupaten Pidie. Hubungan antara variabel dependen dan independen yaitu masing-masing variabel Pelatihan(X1) dan Pemberian Reward (X2),terhadapKepuasan Kerja (Y) Pegawai di Badan Pusat Statistik Kabupaten Pidie dengan indeks korelasi sebesar 91,0 \% Ini berarti hubungan tersebut sangat kuat.Kemudian indeks determinasi masingmasing Penelitian (X1) dan Pemberian Reward (X2) sebesar 82,8\%, ini berartikedua variabelberpengaruh secara signifikan terhadap Kepuasan Kerja Pegawai di Badan Pusat Statistik Kabupaten Pidie, dan sebesar 17,2\% yang dipengaruhi oleh variabel lain yang tidak diteliti dalam penelitian ini.
\end{abstract}

Kata kunci : Pelatihan, Pemberian Reward,Kepuasan Kerja

\section{Latar BelakangPenelitian}

Manajemen sumber daya yang baik dapat membantu Pemerintah untuk mendapatkan pegawai yang tepat sesuai dengan yang dibutuhkan.Pegawai dalam suatu Pemerintah adalah pegawai yang mempunyai kemampuan sesuai dengan lowongan jabatan yang ada dalam perusahaaan.Hal ini dimaksudkan agar pegawai bekerja secara efektif dan efisien dan yang terpenting sasaran Pemerintah dapat tercapai. Dengan diselenggarakan suatu bentuk pelatihan secara terarah, bertahap, dan terus-menerus merupakan salah satu jalan yang efektif dan efisien untuk merubah perilaku dan kemampuan yang dimiliki oleh pegawai tersebut, disamping itu dengan diadakan pelatihan para pegawai akan lebih memahami maksud, tujuan dan tugas pokokPemerintah.

Setiap Pemerintah harus mampu mengembangkan diri sendiri agar memiliki suatu keunggulan yang kompetitif.Untuk dasar yang mantap, seluruh aspek dan sumber daya yang terdapat di Pemerintah merupakan faktorfaktor yang memerlukan perhatian penuh dalam manajemen.Pelatihan selalu dibutuhkan baik bagi pegawai baru maupun pegawai lama. Pegawai baru mutlak diberi pelatihan agar ia memiliki pengetahuan yang memadai tentang jabatannya, sehingga ia mampu mengerjakan tanggung jawabnya sesuai dengan apa yang diharapkan oleh Pemerintah. Pegawai lama perlu mengikuti pelatihan untuk mempersiapkan dirinya ketika akan ditransfer atau menghadapi promosi untuk menduduki jabatan yang lebih tinggi.

Latihan merupakan proses yang berlangsung secara terus menerus dan merupakan bukan proses sesaat. Masalahmasalah baru, prosedur-prosedur baru, peralatan, perkembangan teknologi, dan jabatan baru akan terus terlaksana yang mendorong agar manajemen terus merencanakan program pelatihan secara kontinyu. 
Sumber daya manusia adalah suatu aspek yang sangat penting bagi kelangsungan hidup dan perkembangan Pemerintah. Kesadaran akan hal itu membuat peran manajer sumber daya manusia berubah dan berkembang secara berkesinambungan. Manajer selalu sumber daya manusia harus dapat menyediakan suatu angkatan kerja yang efektif bagi organisasi sekaligus memberi perhatian besar terhadap harapan dan kebutuhan tenaga kerja yang bersangkutan. Sumber daya manusia yang berkualitas adalah Sumber daya manusia yang memiliki keterampilan, kemampuan, pengetahuan, dan sikap yang baik dalam bekerja. Oleh karenanya, pihak Pemerintah harus mengambil langkah-langkah agar dapat mengembangkan dan meningkatkan kualitas dari kemampuan sumber daya manusia yang dimiliki Pemerintah seperti kemampuan teknis, kemampuan konseptual, dan kemampuan berinteraksi.

Salah satu program untuk memperoleh sumber daya manusia yang berkualitas adalah program pengembangan pegawai melalui pelatihan. Program ini dinilai cukup baik karena dapat meningkatkan kemampuan pegawai yang dimiliki Pemerintah sehingga dengan bekal keterampilan yang diperoleh selama pelatihan para pegawai tersebut dapat membantu Pemerintah mencapai tujuan Pemerintah serta mampu mendukung daya saing Pemerintah secara berkesinambungan. Adapun dalam melaksanakan program pelatihan ini harus diperlukan suatu perencanaan yang baik, sistematis, dan terarah.Sehingga hasil dari program ini dapat membermasukan yang positif bagi Pemerintah.Selain itu karena biaya untuk melakukan program ini cukup besar maka program pelatihan ini harus berhasil. .

Pemberian reward atau penghargaan kepada pegawai yang berprestasi akan memberikan motivasi kepada pegawai untuk lebih meningkatkan produktivitasnya dalam bekerja. Dengan pegawai yang semakin produktif akan dapat meningkatkan kinerja Pemerintah. Selain itu Pemerintah dengan kinerja yang tinggi juga akan dapat meningkatkan kesejahteraan pegawainya.

Selain reward Pemerintah juga harus memberikan sanksi kepada pegawai yang malas atau lalai dalam bekerja. Karena hal itu akan mengganggu kinerja peagawai lain. Dengan pemberian sanksi yang sesuai maka diharapkan akan meningkatkan kinerja pegawai tersebut dan tidak akan mengulangi kesalahannya lagi.
Pengaruh pelatihan dan pemberian reward merupakan kedua hal yang sangat penting dan harus dilakukan oleh para Pegawai Badan Pusat Statistik Kabupaten Pidie menganalisi tentang pelatihan yaitu proses pembelajaran yang lebih menekankan praktek dari pada teori oleh seseorang atau kelompok dengan menggunakan pendekatan berbagai pembelajaran dan bertujuan meningkatkan kemampuan dalam satu atau beberapa jenis keterampilan tertentu.

Dalam dunia kerja, kita akrab mendengar dengan istilah pelatihan kerja atau training, sumber daya manusia dalam suatu Pemerintah merupakan aset penting bagi perkembangan Pemerintah, untuk meningkatkan kualitas dan keterampilan kerja para pegawai, banyak Pemerintah mengadakan pelatihan kerja/training. Pemberian reward (penghargaan) merupakan upaya Pemerintah dalam memberikan balas jasa atas hasil kerja pegawai sehingga dapat mendorong pegawai bekerja lebih giat dan berpotensi. Pegawai memerlukan suatu penghargaan pada saat hasil kerjanya telah memenuhi atau bahkan melebihi standar yang telah ditentukan oleh Pemerintah. Pegawai bekerja mempunyai tujuan antara lain untuk memperoleh penghasilan agar kebutuhan dan keinginannya dapat direalisasikan. Seorang pegawai akan mendapatkan kepuasan kerja jika mempersepsikan bahwa imbalan yang diterimanya baik berupa gaji, insentif, tunjangan dan penghargaan lainya yang tidak berbentuk materi, atas pelaksanaan pekerjaan yang dilakukannya nilainya lebih tinggi daripada pengorbanannya berupa tenaga dan ongkos yang telah dikeluarkannya untuk melaksanakan pekerjaan itu.

Seiring berkembangnya ilmu dan pengetahuan yang makin maju maka pemerintah dituntut untuk lebih dapat menjadikan pegawainya lebih terampil dan terlatih dalam mengerjakan tugasnya. Oleh karena itu kantor Pusat Statistik Kabupaten Pidie berinisiatif untuk mengadakan progam pelatihan dan pemberian reward bagi pegawai, karena pelatihan dan pemberian reward membuat mereka lebih percaya diri dan semangat sehingga menimbulkan rasa puas dalam bekerja dan lebih dihargai, serta mampu berusaha untuk meningkatkan produktivitas kerja pegawai.

Berdasarkan hal tersebut, penulis tertarik untuk mengadakan penelitian dengan judul: "Pengaruh Pelatihan Dan Pemberian Reward 
Terhadap Kepuasan Kerja Pegawai Badan Pusat Statistik Kabupaten Pidie ”.

\section{Rumusan Masalah}

Berdasarkan latar belakang diatas, maka permasalahan yang akan dikaji dalam penelitian ini adalah :

1. Apakah pelatihan berpengaruh terhadap kepuasan kerja pegawai badan pusat statistik kabupaten pidie?

2. Apakah pemberian reward berpengaruh terhadap kepuasan kerja pegawai badan pusat statistik kabupaten pidie?

3. Apakah pelatihan danpemberian reward berpengaruh terhadap semangat kerja pegawai badan pusat statistik kabupaten pidie?

\section{Tujuan penelitian}

Tujuan yang hendak dicapai dalam penelitian ini adalah :

1. Untuk mengetahui pengaruh pelatihan terhadap kepuasan kerja pegawai badan pusat statistik kabupaten pidie.

2. Untuk mengetahui pengaruh pemberian reward terhadap kepuasan kerja pegawai badan pusat statistik kabupaten pidie.

3. Untuk mengetahui pengaruh pelatihan dan pemberian reward secara bersamasama untuk mencapai kepuasan kerja pegawai badan pusat statistik kabupaten pidie.

\section{Manfaat penelitian}

Hasil penelitian ini diharapkan dapat memberikan sumbangan bagi pihak yang berkepentingan antara lain sebagai berikut :

1. Bersifat Teoritis :

a. Sebagai sarana untuk melatih berfikir secara ilmiah dengan berdasar pada disiplin ilmu yang diperoleh di bangku kuliah khususnya lingkup manajemen sumber daya manusia.

b. Untuk menambah informasi sumbangan pemikiran dan pengetahuan dalam penelitian.I

2. Bersifat Praktis :

Bagi Pegawai Badan Pusat Statistik Kabupaten Pidie khususnya, untuk mengetahui sejauh mana pelatihan dan pemberian reward berdampak pada Kinerja yang diharapkan Pemerintah, dan hasilnya menjadi pertimbanagan dalam menyusun Strategi untuk meningkatkan semangat kerja pegawai

\section{Pegertian Pelatihan}

Pelatihan menurut Wilson (2012:202) adalah suatu proses memperbaiki keterampilan kerja pegawai untuk membantu pencapaian tujuan perusahaan. Pada awalnya pelatihan kerja hanya diperuntukkan kepada tenaga-tenaga operasional, agar keterampilan secara teknis. Tetapi, kini pelatihan diberikan kepada setiap pegawai dalam perusahaan termasuk pegawai administrasi maupun tenaga manjerial.

Idealnya, pelatihan harus dirancang untuk mewujudkan tujuan - tujuan organisasi, yang pada waktu bersamaan juga mewujudkan tujuan - tujuan para pekerja secara perorangan. Pelatihan sering dianggap sebagai aktivitas yang paling umum dan para pimpinan mendukung adanya pelatihan karena melalui pelatihan, para pekerja akan menjadi lebih trampil dan karenanya akan lebih produktif sekalipun manfaat - manfaat tersebut harus diperhitungkan dengan waktu yang tersita ketika pekerja sedangdilatih.

Menurut Rivai, (2009 : 211) Pelatihan merupakan wahana untuk membangun SDM menuju era globalisasi yang penuh dengan tantangan. Karena itu, kegiatan pelatihan tidak dapat diabaikan begitu saja terutama dalam memasuki era persaingan yang semakin ketat, tajam, berat pada abad milenium ini. Berkaitan dengan hal tersebut kita menyadari bahwa pelatihan merupakan fundamental bagi pegawai.

Menurut Dessler (2006:280) bahwa "Pelatihan merupakan proses mengajar ketrampilan yang dibutuhkan pegawai untuk melakukan pekerjaannya".Selanjutnya pengertian pelatihan secara sederhana didefinisikan oleh Pramudyo (2007:16) sebagai "Proses pembelajaran yang dirancang untuk mengubah kinerja orang dalam melakukan pekerjaannya".

\section{MetodePelatihan}

Menurut Wilson (2012:210) ada beberapa metode dalam pelatihan tenaga kerja, antara lain on the job training dan off the job training.

1. On the job training

Metode On the job training merupakan metode yang paling banyak digunakan perusahaa, dalam pelatihan tenaga kerjannyaa. para pegawai mempelajari pekerjaanya sambil mengerjakannya secara langsung. Kebanyakan perusahaan menggunakan orang dalam perusahaan uang melakukan pelatihan rerhadap sumber daya manusianya, biasanya oreh atasan langsung.Adapun empar metode yang digunakan 
antara lain, rotasi pekerjaan, penugasan yang direncanakan, pembimbingan, dan pelatihan posisi.

Rotasi pekerjaan (job rotation), merupakan pemindahan pekerjaan dari satu pekerjaan ke pekerjaan lainnya dalam organisasi,sehingga dapat menambah pengetahuan dan pengalaman tenaga kerja.

Penugasan yang direncanakan, menugaskan tenaga kerja untukmengembangkan kemampuan dan pengalamannya tentang pekerjaanya. Pembimbingan, pelatihan tenaga kerja langsung oleh atasannya.Metode ini sangat efektif dilakukan karena atasan langsung sangat mengetahui bagaimana keterampilan bawahannya, sehingga lebih tahu menerapkan metode yang digunakan.

Pelatihan posisi, tenaga kerja yang dilatih untuk dapat menduduki suatu posisi tertentu. pelatihan seperti ini diberikan kepada tenaga kerja yang mengalami permindahan pekerjaan. sebelum dipindahkan ke pekekerjaan baru terlebih dahulu diberikan pelatihan agar mereka dapar mengenal rebih dalam lentang pekerjaannya.

\section{Metode Off-The-Job Training}

Dalam merode Metode Off-The-Job Training,pelatihan dilaksanakan dimana pegawai dalam keadaan tidak bekerja dengan tujuan agar terpusat pada kegiatan pelatihan saja. Pelatih didatangkan dari luar organisasi atau para peserta mengikuti pelatihan di luar organisasi. Hal ini dilakukan karenaa kurang atau tidak tersedianya pelatih dalam perusahaan. Keuntungan dengan metode ini, para peserta latihan tidak merasa jenuh dilatih oleh atasannya langsung, metode yang diajarkan pelatih berbeda sehingga memperluas pengetauhan.

Metode ini dapat diiakukan dengan beberapa teknik antara lain:

Business games, peserta dilatih dengan memecahkan suatu masalah, sehingga.para peserta dapat belajar dari masalah yang sudah pernah terjadi pada suatu perusahaan tertentu. Metode ini bertujuan agar para peserta latihan dapat dengan lebih baik dalam pengambilan keputusan dan cara mengelola operasional perusahaan dengan baik.

Vestibule school, tenaga kerja dilatih dengan menggunakan peralatan yang sebenarnya dan sistem pengaturan sesuai dengan yang sebenarnya tetapi dilaksanakan di luar perusahaan.

Case stuily, di mana peserta dilatih untuk mencari penyebab timbulnya suatu masalah, kemudian dapat memecahkan masalah tersebut. pemecahan masalal dapat dilakukan secara individual atau kelompok atas masalah-masalah yang ditentukan.

Selanjutnya menurut Barry (2007 : 116), maksud dilaksanakan pelatihan adalah untuk

1. Pengembangan keahlian dan kemampuan individu untuk memperbaiki kinerja.

2. Membiasakan pegawai dengan sistem, prosedur dan metode kerja yang baru.

3. Membantu pendatang baru menjadi terbiasa dengan persyaratan pekerjaan tertentu dan persyaratan organisasi.

Menurut Rivai (2009 : 241), mengemukakan beberapa metode pelatihan yang dapat dipakai adalah sebagai berikut :

1. On the job training

On the job training (TO) atau disebut juga dengan pelatihan dengan instruksi pekerjaan sebagai suatu metode pelatihan dengan cara para pekerja atau calon pekerja ditempatkan dalam kondisi pekerjaan yang riil.

2. Rotasi

Untuk pelatihan silang (croos-train) bagi pegawai agar mendapatkan variasi kerja, para pengajar memindahkan para peserta pelatihan dari tempat kerja yang satu ke tempat kerja yang lainnya.

3. Magang

Magang melibatkan pembelajaran dari pekerja yang lebih berpengalaman, dan dapat ditambah pada teknik off the job traning.

4. Ceramah Kelas dan Presentasi Vidio

Ceramah dan teknik lain dalam off the job training tampaknya mengandalkan komunikasi daripada memberi model. Televise, film, slide dan film pendek sama dengan ceramah.

5. Pelatihan Vestibule

Agar pelatihan tidak mengganggu operasional rutin, beberapa perusahaan menggunakan pelatihan Vestibule. Wilayah atau vestibule terpisah dibuat dengan peralatan yang sama dengan yang digunakan dalam pekerjaan.

6. Permainan Peran model perilaku Permainan peran alat yang mendorong peserta untuk membayangkan identitas lain. Teknik ini juga digunakan untuk mengubah sikap dan membantu mengembangkan keterampilan interpersonal. 
7. Case Study

Metode kasus adalah metode pelatihan yang menggunakan deskripsi tertulis dari suatu permasalahan riil yangb dihadapi oleh perusahaan atau perusahaan lain. Dengan mempelajari suatu kasus, para peserta pelatihan mempelajari suatu keadaan yang bersifat riil.

8. Simulasi

Permainan simulasi dapat dibagi dua macam yaitu :

a. Simulasi yang menyebabkan simulatoryang bersifat mekanik (mesin) yang mengandalkan aspekaspek utama dalam suatu situasi kerja.

b. Simulasi computer, untuk tujuan pelatihan dan pengembangan, metode ini sering berupa games atau permainan.

9. Belajar Mandiri dan Proses Belajar Terprogram

Teknik belajar mandiri berkisar pada cara manual sampai kaset rekaman atau video. Dan bahan-bahan pembelajaran terprogram adalah bentuk lain dari belajar mandiri, biasanya terdapat program computer atau cetakan booklet yang berisi pertanyaan dan jawaban.

10. Praktik Laboraturium

Pelatihan dilaboraturium dirancang untuk meningkatkan keterampilan interpersonal.

11. Pelatihan Tindakan (Action Learning)

Pelatihan terjadi dalam kelompok kecil yang berusaha mencari solusi masalah nyata yang di hadapi oleh perusahaan, dibantu fasilitator.

12. Role Playing

Role playing adalah metode pelatihan yang merupakan perpaduan antara metode kasus dan program pengembangan sikap dan program pengembangan sikap.

13. In-basket Technique

Melalui metode in-basket technique, para peserta diberikan materi yang berisikan berbagai informasi, seperti email khusus dari manajer, dan daftar telepon.

14. Management games
Management games menekankan pada pengembangan kemampuan problemsolving.

15. Behaviour modeling

Modeling adalah sebagai salah satu proses yang bersifat psikologis mendasar dimana pola-pola baru dari suatu perilaku yang dapat diperoleh sedangkan pola-pola yang sudah ada dapat diubah.

16. Outdor Oriented Programs

Program ini biasanya dilakukan disuatu wilayah yang terpencil dengan melakukan kombinasi antara kemampuan diluar kantor dengan kemampuan diruang kelas.

\section{Pengertian Pemberian Reward}

Reward merupakan sebagai bentuk apresiasi usaha untuk mendapatkan tenaga kerja yang profesional sesuai dengan tuntutan jabatan diperlukan suatu pembinaan yang berkeseimbangan, yaitu suatu usaha kegiatan perencanaan, pengorganisasian, penggunaan, dan pemeliharaan tenaga kerja agar mampu melaksanakan tugas dengan efektif dan efisien. Sebagai langkah nyata dalam hasil pembinaan maka diadakan pemberian reward pegawai yang telah menunjukan prestasi kerja yang baik (Handoyo, 2005:103).

Menurut Simamora(2005:514) "reward adalah insentif yang mengaitkan bayaran atas dasar untuk dapat meningkatkan produktivitas para pegawai guna mencapai keunggulan yang kompetitif". Dengan adanya pendapat para ahli diatas maka dapat disimpulkan bahwa pemberian reward dimaksudkan sebagai dorongan agar pegawai mau bekerja dengan lebih baik sehingga dapat meningkatkan kinerja pegawai.

Pemberian reward tersebut merupakan upaya perusahaan dalam memberikan balas jasa atas hasil kerja pegawai, sehingga dapat mendorong pegawai bekerja lebih giat dan berpotensi. Pegawai memerlukan suatu reward pada saat hasilkerjanya telah memenuhi atau bahkan melebihi standar yang telah ditentukan oleh perusahaan. Reward ini dapat berupa pujian. Tidak hanya pegawai yang melakukan kesalahan memperoleh makian dari pimpinan. Pegawai bekerja mempunyai tujuan, antara lain untukmemperolehpenghasilanagar kebutuhandankeinginannya dapatdirealisasikan.

Reward adalah ganjaran, hadiah, penghargaan atau imbalan yang bertujuan agar 
seseorang menjadi lebih giat lagi usahanya untuk memperbaiki atau meningkatkan kinerja yang telah dicapai" (Nugroho, 2006:5)

Hubungan antara penghargaan dan kepuasan tidak sepenuhnya dipahami, dan juga tidak statis. Hubungan tersebut berubah karena orang dan lingkungannya berubah. Akan tetapi, terdapat beberapa pertimbangan penting yang dapat digunakan manajer untuk mengembangkan dan mendistribusikan penghargaan. (John, dkk : 2007 : 227)

\section{Fungsi dan TujuanReward}

Tujuan utama dari program penghargaan menurut (John, dkk : $2007: 226$ ) adalah:

1. Menarik orang yang memiliki kualifikasi untuk bergabung dengan organisasi.

2. Mempertahankan karyawan agar terus datang untuk bekerja, dan

3. Memotivasi karyawan untuk mencapai tingkat kinerja yang tinggi.

Menurut Handoko

mengemukakan beberapa fungsi reward sebagai berikut:

1. Memperkuat motivasi untuk memacu diri agar mencapaiprestasi.

2. Memberikan tanda bagi seseorang yang memiliki kemampuanlebih.

3. BersifatUniversal.

Adapun tujuan reward seperti yang dikemukakan oleh Taylor (dalam Manullang, 2006:184) menyatakan tujuan reward adalah sebagai berikut :

1. Menarik

(merangsang)seseorangagarmaubergabu ngdengan perusahaan.

2. Mempertahankan pegawai yang ada agar tetap mau bekerja di perusahaan.

3. Memberi lebih banyak dorongan agar para pegawai tetap berprestasi.

Pencapaian tujuan perusahaan agar sesuai dengan yang diharapkan maka fungsi reward harus dilakukan sebelum terjadinyapenyimpangan- penyimpangan sehingga lebih bersifat mencegah dibandingkan dengan tindakan - tindakan reward yang sesudah terjadinya penyimpangan. Oleh karena itu, tujuan reward adalah menjaga hasil pelaksanaan kegiatan sesuai dengan rencana, ketentuan - ketentuan dan instruksi yang telah ditetapkan benar - benar diimplementasikan, sebab reward yang baik akan tercipta tujuan reward.
Menurut Rivai (2009:767) Tujuan utama dari insentif adalah untuk memberikan tanggungjawab dan dorongan kepada pegawai dalam rangka meningkatkan kualitas dan kuantitas hasl kerjanya. Sedangkan bagi perusahan, insentif merupakan strategi untuk meningkatkan produktivitas dan efesiensi perusahan dalam menghadapi persaingan yang semakin ketat, dimana produktivitas menjadi satu hal yang sangat penting.

\section{METODE PENELITIAN}

1. Lokasi dan Objek Penelitian

Penelitian ini dilakukan pada Badan Pusat Statistik Kabupaten Pidie. Sedangkan Obyek Penelitian ini akan membahas tentang deskripsi perusahaan, deskripsi responden, dan analisis indeks jawaban responden per variabel independen dan dependen.

2. Populasi dan Sampel

Populasi

Menurut Sugiyono (2010:117) populasi adalah wilayah generalisasi yang terdiri atas obyek/ subyek yang mempunyai kualitas dan karakteristik tertentu yang ditetapkan oleh peneliti untuk dipelajari dan kemudian ditarik kesimpulannya. Dalam penelitian ini populasi penelitian adalah pegawai yang bekerja padaBadan Pusat Statistik Kabupaten Pidie yang berjumlah 34 Pegawai.

Sampel

Menurut Sudjana (2012: 6), sampel adalah sebagian yang diambil dari populasi atau sampel adalah sebagian atau wakil dari populasi yang hendak diteliti. Untuk melakukan sebuah penelitian, tidak harus ditelitikeseluruhan anggotapopulasiyangada.

Menurut Arikunto (2008:116) "Penentuan pengambilan Sample sebagai berikut :

Apabila kurang dari 100 lebih baik diambil semua hingga penelitiannya merupakan penelitian populasi. Jika jumlah subjeknya besar dapat diambil antara $10-15 \%$ atau $20-55 \%$ atau lebih tergantung sedikit banyaknya dari:

1) Kemampuan peneliti dilihat dari waktu, tenaga dan dana

2) Sempit luasnya wilayah pengamatan dari setiap subyek, karena hal ini menyangkut banyak sedikitnya dana.

3) Besar kecilnya resiko yang ditanggung oleh peneliti untuk peneliti yang resikonya besar, tentu saja jika samplenya besar hasilnya akan lebih baik. 
Berdasarkan teori tersebut, maka penulis mengambil seluruh populasi sebagai sampel yang berjumlah 34. Dengan itu penelitian ini merupakan penelitian populasi.

\section{Teknik Pengumpulan Data \\ Data Primer}

Data primer adalah data yang dikumpulkan dan diolah sendiri oleh peneliti langsung dari responden berupa data opini dan kuesioner yang disebarkan.Kuesioner berisi daftar pertanyaan yang terstruktur dan materinya berhubungan dengan pelatihan dan Pemberian Reward secara parsial dan simultan terhadap Kepuasan Kerja.

\section{Data Sekunder}

Data sekunder merupakan data yang diperoleh secara tidak langsung, yaitu data yang diperoleh dan diolah dari sumber Badan Pusat Statistik Kabupaten Pidiemaupun dari internet, dan sebagainya.

\section{Skala Pengukuran}

Data hasil penelitian penelitian yang diperoleh melalui penyebaran kuisioner dalam bentuk kualitatif dikomposisikan terlebih dahulu agar menjadi data kuantitatif. Adapun nilai kuantitatif yang dikomposisikan dilakukan dengan menggunakan Skala Likert dan untuk satu pilihan dinilai dengan jarak interval 1 . Nilai dari pilihan tersebut antara lain : 1,2,3,4,5. Masing-masing pilihan tersebut dapat dilihat dalam tabel dibawah ini:

Tabel 3.1

Skala Likert

\begin{tabular}{|c|l|c|}
\hline No & \multicolumn{1}{|c|}{$\begin{array}{c}\text { Keterangan } \\
\text { (pilihan) }\end{array}$} & Skor \\
\hline 1 & Sangat setuju & 5 \\
2 & Setuju & 4 \\
3 & Kurang Setuju & 3 \\
4 & Tidak setuju & 2 \\
5 & Sangat tidak setuju & 1 \\
\hline
\end{tabular}

\section{Operasional Variabel}

Definisi variabel adalah obyek penelitian atau apa yang menjadi titik perhatian suatu penelitian. Dalam penelitian ini digunakan sejumlah variabel yang dibagi menjadi dua bagian yaitu : variabel independen (variabel bebas) dan variabel dependen (variabel terikat). Definisi operasional masing-masing variable adalah sebagai berikut :
Tabel 3.2

Definisi Operasional Variabel

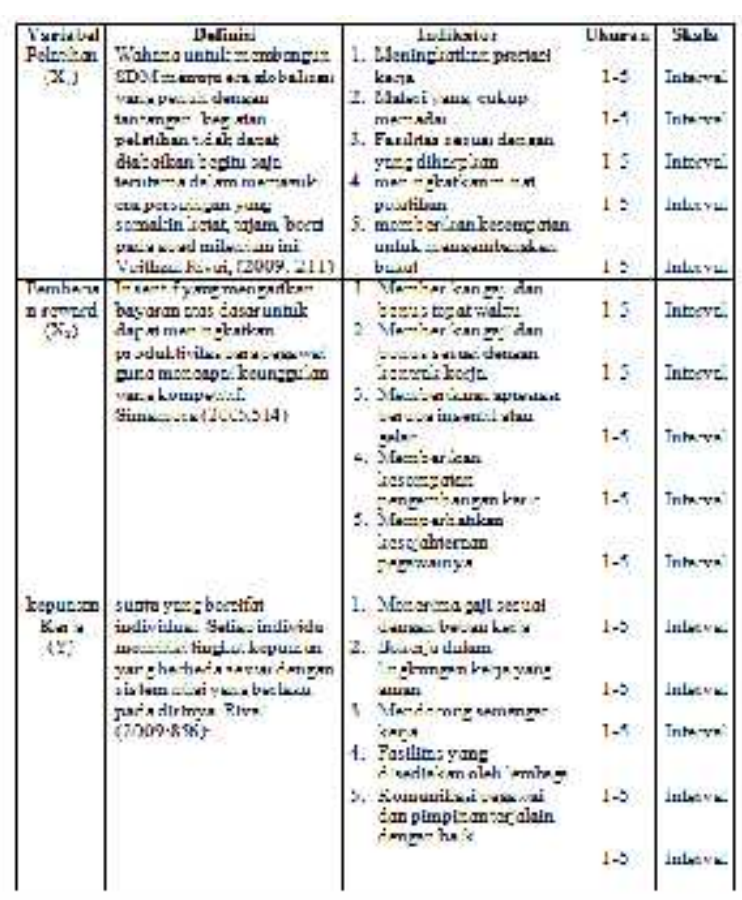

\section{Peralatan Analisis Data}

Analisis statistik yang digunakan dalam penelitian ini adalah analisis regresi berganda dengan menggunakan program SPSS. Analisis regresi, untuk menghitung besarnya pengaruh secara kuantitatif dari suatu perubahan kejadian (variabel X) terhadap kejadian lainnya (variabel Y).Untuk melihat hubungan antara variabel yang dipergunakan rumus regresi berganda Umar (2008: 256).

$$
\mathrm{Y}=\mathrm{a}+\mathrm{b} 1 \mathrm{X} 1+\mathrm{b} 2 \mathrm{X} 2+\mathrm{e}
$$

Dimana:

$$
\begin{array}{ll}
\mathrm{Y} & =\text { Kepuasan Kerja } \\
\mathrm{a} & =\text { Konstanta } \\
\mathrm{b} 1, \mathrm{~b} 2 & =\text { Koefisien regresi variabel } \\
\mathrm{X} 1 & =\text { Pelatihan } \\
\mathrm{X} 2 & =\text { Pemberian Reward } \\
\mathrm{e}=\text { error } &
\end{array}
$$

\section{Pengujian Validitas dan Reabilitas Uji Validitas}

Uji validitas digunakan untuk mengukur sah atau tidaknya suatu kuesioner. Suatu kuesioner dikatakan sah jika pertanyaan pada kuesioner mampu mengungkapkan sesuatu yang akan diukur oleh kuesioner tersebut. Uji validitas dilakukan dengan membandingkan nilai $r$ hitung (untuk setiap butir dapat dilihat pada kolom corrected item-total correlations dengan $\mathrm{r}$ table untuk degree of freedom $(\mathrm{df})=$ $\mathrm{n}-\mathrm{k}$, dalam hal ini $\mathrm{n}$ adalah jumlah sampel dan $\mathrm{k}$ 
adalah jumlah item. Jika $r$ hitung $>r$ tabel, maka pertanyaan tersebut dikatakan valid (Ghozali, 2005: 45 ).

Uji Reliabilitas

Uji Reliabilitas merupakan alat untuk mengukur suatu kuesioner yang merupakan indikator dari variabel atau konstruk. Suatu kuesioner dikatakan reliable atau handal jieseorang terhadap pertanyaan konsisten atau stabil dari waktu ke waktu. SPSS memberikan fasilitas untuk mengukur reliabilitas dengan uji statistik Cronbach Alpha $(\alpha)$.

Pengujian Asumsi Klasik

Uji Multikolonieritas

Uji multikolonieritas bertujuan untuk menguji apakah dalam model regresi ditemukan adanya korelasi antar variabel bebas. Model regresi yang baik seharusnya tidak terjadi korelasi diantara variabel bebas. Jika variable bebas saling berkorelasi, maka variabel-variabel ini tidak ortogonal adalah variabel bebas yang nilai korelasi antar sesama variabel bebas sama dengan nol (Ghozali, 2005: 91).

Multikolonieritas dideteksi dengan menggunakan nilai tolerance dan variance inflation factor (VIF). Tolerance mengukur variabilitas variable bebas yang terpilih yang tidak dapat dijelaskan oleh variabel bebas lainnya. Jadi nilai tolerance yang rendah sama dengan nilai VIF yang tinggi (karena $\mathrm{VIF}=1 /$ tolerance) dan menunjukkan adanya kolinearitas yang tinggi. Nilai cutoff yang umum dipakai adalah nilai tolerance 0,10 atau sama dengan nilai VIF dibawah 10 (Ghozali, 2005: 92).

Uji Heteroskedastisitas

Uji heteroskedastisitas bertujuan untuk mengetahui apakah dalam model regresi terjadi ketidaksamaan varian dari suatu residual pengamatan ke pengamatan yang lain. Salah satu cara untuk mendekati heteroskedastisitas adalah dengan melihat grafik scatter plot antara nilai prediksi variabel terikat (ZPRED) dengan residualnya (SRESID). Jika ada titik-titik membentuk pola tertentu yang teratur seperti bergelombang, melebar, kemudian menyempit maka telah terjadi heteroskedastisitas. Jika titiktitik menyebar di atas dan di bawah angka 0 pada sumbu $\mathrm{Y}$ tanpa membentuk pola tertentu maka tidak terjadi heteroskedastisitas (Ghozali, 2005: 105).

Uji Normalitas

Bertujuan untuk menguji apakah dalam sebuah model regresi, variabel dependen, variabel independen, atau keduanya mempunyai distribusi normal atau tidak. Model regresi yang baik adalah berdistribusi normal atau mendekati normal. Suatu data dikatakan mengikuti distribusi normal dilihat dari penyebaran data pada sumbu diagonal dari grafik (Ghozali, 2005: 110).

Dasar pengambilan keputusan adalah sebagai berikut :

1) Jika data menyebar disekitar garis diagonal dan mengikuti arah garis diagonal, maka model regresi memenuhi normalitas.

2) Jika data menyebar jauh dari garis diagonal dan tidak mengikuti arah garisdiagonal, maka model regresi tidak memenuhi normalitas.

\section{Pengujian Hipotesis}

H0 : Variabel-variabel bebas (Pelatihandan

Pemberian Reward) tidak berpengaruh terhadap variabel terikat (Kepuasan Kerja) Pegawai Badan Pusat Statistik Kabupaten Pidie.

Ha : Adanya pengaruh variabel-variabel bebas (Pelatihandan Pemberian Reward) secara signifikan terhadap variabel terikat (Kepuasan Kerja) Pegawai Badan Pusat Statistik Kabupaten Pidie.

Untuk menguji Hipotesis dalam penelitian ini penulis menggunakan uji $\mathrm{F}$ dan uji t yaitu pada tingkat keyakinan (convindend interval 95\%) atau tingkat kesalahannya (alpha) $\alpha$ sebesar 0.05. Pada tingkat keyakinan (convided interval 95\%) atau tingkat kesalahan (alpha) $\alpha$ sebesar 0,05 maka apabila nilai signifikan < dari nilai alpha (5\%) maka $\mathrm{Ha}$ di terima dan sebaliknya apabila nilai signifikan $>$ dari nilai alpha (5\%) maka Ha di tolak.

Untuk mempercepat perhitungan dalam penelitian ini digunakan alat bantu komputer melalui software SPSS (statistic package for social science) versi 21.0.

\section{Hasil Penelitian}

1. Pengaruh Pelatihan dan Pemberian Reward terhadap Kepuasan Kerja Pegawai Badan Pusat Statistik Kabupaten Pidie

Untuk mengetahui pengaruh Variabel Penelitian dan Pemberian Reward terhadap Kepuasan Kerja Pegawai Badan Pusat Statistik Kabupaten Pidie, maka dilakukan analisis data melalui regresi linear berganda. Di mana hasilnya dapat dilihat pada Tabelberikut:

Tabel 4.1

Pengaruh Masing-masing Variabel Independen Terhadap Variabel Dependen 


\begin{tabular}{|c|c|c|c|c|c|c|}
\hline Nama Yartabet & B & $\begin{array}{l}\text { Kantsir } \\
\text { Lrror }\end{array}$ & Det2 & A. $=$ & $t_{\text {izite }}$ & Sign \\
\hline Kourtz: & 4.120 & $15 \% 6$ & & $2 \times 24$ & 1,696 & 0005 \\
\hline Fedati:an $\left(x_{y}\right)$ & II) 4 41 & oplat & पIST & गतार & 1,696 & 0.002 \\
\hline 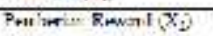 & 0,293 & 505 & 0,056 & उसका & काम & Op.5 \\
\hline 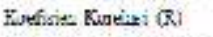 & & $-0,910$ & & & & \\
\hline Fuefiste Delawiati $\mathbb{R}^{2}$ & & $-0.32:$ & & & & \\
\hline 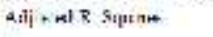 & & $-n .317$ & & & & \\
\hline thas & & $-11, x+4$ & & & & \\
\hline$r_{n \times 1}$ & & $-8,10$ & & & & \\
\hline$x_{n+1}+2$ & & $(+6)$ & & & & \\
\hline
\end{tabular}

Sumber: Data Primer Penelitian Diolah, (2017)

Dari output SPSS di atas dengan dipergunakan model regresi berganda, dapat difungsikan dalam bentuk persamaan sebagai berikut:

$\mathrm{Y}=4,120+0,540 \mathrm{X} 1+0,283 \mathrm{X} 2$

Dari persamaan regresi linear berganda di atas dapat dijelaskan sebagai berikut:

1. Nilai konstanta sebesar 4,120 artinya jika Pelatihan (X1) dan Pemberian Reward (X2)dianggap konstan, maka Kepuasan Kerja Pegawai Badan Pusat Statistik Kabupaten Pidieadalah sebesar 4,120 pada satuan skala likert, yang mengindikasikan bahwa Kepuasan Kerja (Y) Pegawai Badan Pusat Statistik Kabupaten Pidie dapat dikatakan sangat baik.

2. Nilai koefisien regresi Pelatihan sebesar 0,540 dapat diartikan bahwa setiap $1 \%$ kenaikan Pelatihan (X1), akan meningkatkan Kepuasan Kerja sebesar 54,0 $\%$. Ini berarti terjadi peningkatan Kepuasan Kerja (Y) Pegawai Badan Pusat Statistik Kabupaten Pidie.

3. Nilai koefisien regresi Pemberian Reward sebesar 0,283 dapat diartikan bahwa setiap $1 \%$ kenaikan Pemberian Reward (X2), akan meningkatkan Kepuasan Kerja sebesar 28,3 $\%$. Ini berarti terjadi peningkatan Kepuasan Kerja (Y) Pegawai Badan Pusat Statistik Kabupaten Pidie.

Berdasarkan hasil analisis di atas dapat disimpulkan bahwa dari kedua variabel yang diteliti, ternyata variabel Pelatihan(X1), mempunyai pengaruh yang paling dominan sebesar 44,8 \% terhadap Kepuasan Kerja (Y) Pegawai Badan Pusat Statistik Kabupaten Pidie.

Hubungan antara variabel dependen dan independen yaitu masing-masing variabel Pelatihan (X1) dan Pemberian Reward (X2)Kepuasan Kerja (Y) Pegawai Badan Pusat Statistik Kabupaten Pidie dengan indeks korelasi sebesar 91,0 \% Ini berarti hubungan tersebut sangat kuat.
Kemudian indeks determinasi masingmasing variabel Pelatihan (X1) dan Pemberian Reward (X2)sebesar 82,8 \%, ini berarti berpengaruh secara signifikan terhadap Kepuasan Kerja (Y) Pegawai Badan Pusat Statistik Kabupaten Pidie yaitu sebesar 17,2 \% yang dipengaruhi oleh variabel lain yang tidak diteliti dalam penelitian ini.

\section{Hasil Pengujian Hipotesis}

Uji F

Uji $\mathrm{F}$ dilakukan untuk melihat pengaruh variabel independen terhadap variabel dependen secara bersama-sama (secara simultan). Pembuktiannya dapat dijelaskan sebagai berikut:

\begin{tabular}{|c|c|c|c|c|c|c|c|}
\hline & Mudel & $\begin{array}{l}\text { Sun of } \\
\text { Squzes }\end{array}$ & Dit & Mkzu Syua : & F & Fulat & $8 \mathrm{E}$ \\
\hline \multirow[t]{3}{*}{ it } & Begessict & 77,138 & 2 & 55,569 & 71,335 & 3.36 & 0,000 \\
\hline & Reilis & 15,392 & 31 & 529 & & & \\
\hline & To:al & 95,527 & 33 & & & & \\
\hline
\end{tabular}

Sumber: Data Primer Penelitian Diolah, (2017)

Hasil pengujian secara simultan di peroleh Fhitung 74,833 > Ftabel 3,30. Dengan demikian hasil perhitungan ini dapat diambil suatu keputusan bahwa menerima hipotesis alternatif (Ha) dan menolak hipotesis nol (Ho), artinya bahwa variabel Pelatihan (X1) dan Pemberian Reward(X2) secara bersama-sama berpengaruh secara signifikan terhadapKepuasan Kerja (Y) Pegawai pada Badan Pusat Statistik Kabupaten Pidie.

\section{Uji t}

Uji t dilakukan untuk melihat signifikan dari pengaruh variabel independen secara individu terhadap variabel dependen (secara parsial). Pembuktian hipotesis secara parsial dapat dijelaskan sebagai berikut:

Tabel 4.3

Hasil Analisis Uji t

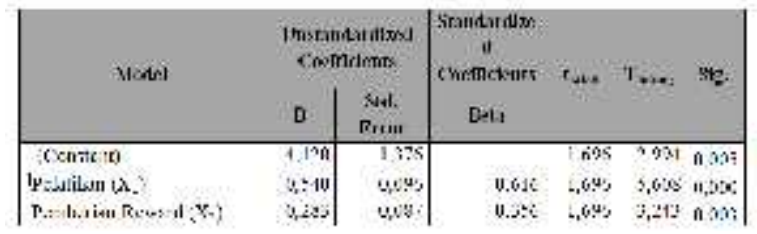

Sumber: Data Primer Penelitian Diolah, (2017)

1. Variabel Pelatihan (X1)diperoleh thitung 5,608>ttabel1,696, sehingga Hipotesis Nol (Ho) ditolak dan Hipotesis Alternatif (Ha) diterima. Dari hasil uji $t$ ini dapat disimpulkan bahwa variabel Pelatihan (X1) 
adapengaruh yang signifikan terhadap Kepuasan Kerja (Y) Pegawai Badan Pusat Statistik Kabupaten Pidie.

2. Variabel Pemberian Reward(X2) diperoleh thitung3,243 >ttabel 1,696, sehingga Hipotesis Nol (Ho) ditolak dan Hipotesis
Alternatif (Ha) diterima. Dari hasil uji t ini dapat disimpulkan bahwa variabelPemberian Reward berpengaruh secara signifikan terhadap Kepuasan Kerja (Y) Pegawai Badan Pusat Statistik Kabupaten Pidie. 